\title{
Pengolahan snack ikan patin sebagai cemilan sehat di Kelurahan Rumbai Bukit Kecamatan Rumbai Kota Pekanbaru
}

\author{
N Ira Sari, Dian Iriani*, Bustari Hasan, \& Tjipto Leksono \\ Universitas Riau \\ * dian.iriani@lecturer.unri.ac.id
}

\begin{abstract}
Abstrak. Ikan patin ini merupakan ikan yang sedang dibudidayakan di Pokdakan Kelurahan Rumbai Bukit Kecamatatan Rumbai Kota Pekanbaru, dengan jumlah produksi 3-6 ton setiap panen. Untuk mengatasi kelimpahan produksi dan memperpanjang masa simpan maka dilakukan usaha diversifikasi olahan hasil perikanan dalam pembuatan snack. Tujuan dari kegiatan pengabdian kepada masyarakat ini adalah memberikan kemampuan dan keterampilan praktis kepada masyarakat kelurahan Rumbai Bukit Pekanbaru dalam pembuatan snack ikan patin aneka flavour yang bernilai gizi tinggi sehingga dapat meningkatkan konsumsi protein ikan bagi anggota keluarga dan diharapkan dapat mengembangkannya dalam bentuk industri skala rumah tangga atau kelompok industri kecil di daerah ini sehingga dapat membantu perekonomian keluarga. Metode yang digunakan berupa metode survey, wawancara, observasi, ceramah, diskusi dan pelatihan pengolahan snack ikan. Hasil yang didapat bahwa masyarakat Kelurahan Rumbai Bukit sangat antusias mengikuti kegiatan pelatihan ini. Berdasarkan post test yang diberikan 95\% masyarakat telah dapat membuat produk olahan ikan berupa snack ikan baik secara perorangan maupun kelompok, mengetahui teknik pengemasan dan pelabelan produk.
\end{abstract}

Kata kunci: cemilan sehat; ikan patin; rumbai bukit; snack ikan

\begin{abstract}
This catfish is a fish that is being cultivated in Pokdakan, Rumbai Bukit village, Rumbai DIstrict, Pekanbaru City, with production of 3-6 tons per harvest. To overcome the abundance of production and extend the shelf life, a diversified processing of fishery products is carried out in making snacks. The purpose of this community service is to provide the ability and practical skills to the community of Rumbai Bukit Village Pekanbaru in making snacks of various flavors of catfish with high nutritional value so that they can increase fish protein consumption for family members and are expected to develop it in the form of a household industry or small industry groups in this area so that it can help the family economy. The method used is a method of survey, interview, observation, lecture, discussion and training on processing fish snacks. The results obtained were that the community of Rumbai Bukit Village was very enthusiastic in participating in this training activity. Based on the post test, $95 \%$ of the community has been able to make processed fish products in the form of fish snacks both individually and in groups, knowing the product packaging and labeling techniques.
\end{abstract}

Keywords: catfish; healthy snack; rumbai bukit village; snack

To cite this article: Ira, N. S., D. Iriani, B. Hasan, \& T. Leksono. 2019. Pengolahan snack ikan patin sebagai cemilan sehat di Kelurahan Rumbai Bukit Kecamatan Rumbai Kota Pekanbaru. Unri Conference Series: Community Engagement 1: 663-669 https://doi.org/10.31258/unricsce.1.663-669

\section{(C) 2019 Authors}

Peer-review under responsibility of the organizing committee of Seminar Nasional Pemberdayaan Masyarakat 2019 


\section{PENDAHULUAN}

Ikan patin (Gambar 1) merupakan salah satu jenis ikan yang memiliki nilai ekonomis yang tinggi dimana selain mudah dibudidayan ikan ini juga mengandung zat gizi yang tinggi yaitu protein $17.63 \%$, abu $1.07 \%$ (Viji et al., 2014), lemak 2.23\% BK, lemak 12.14\%, kadar air 81.57\%, asam lemak jenuh 47.15\%, MUFA 40.41\%, dan PUFA 12.45\% (Domiszewski et al., 2011). Menurut (Oyewole dan Amosu, 2012) bahwa makan ikan setiap minggu dapat mengurangi risiko penyakit jantung dan stroke dengan mengurangi peradangan dan gumpalan darah, meningkatkan elastisitas pembuluh darah, menurunkan tekanan darah, menurunkan lemak darah dan meningkatkatkan kolesterol 'baik', selain itu asam lemak omega-3 pada ikan dapat mengurangi risiko berbagai jenis kanker hingga 30 hingga 50 persen terutama rongga mulut, kerongkongan, usus besar, payudara, ovarium, dan prostat.

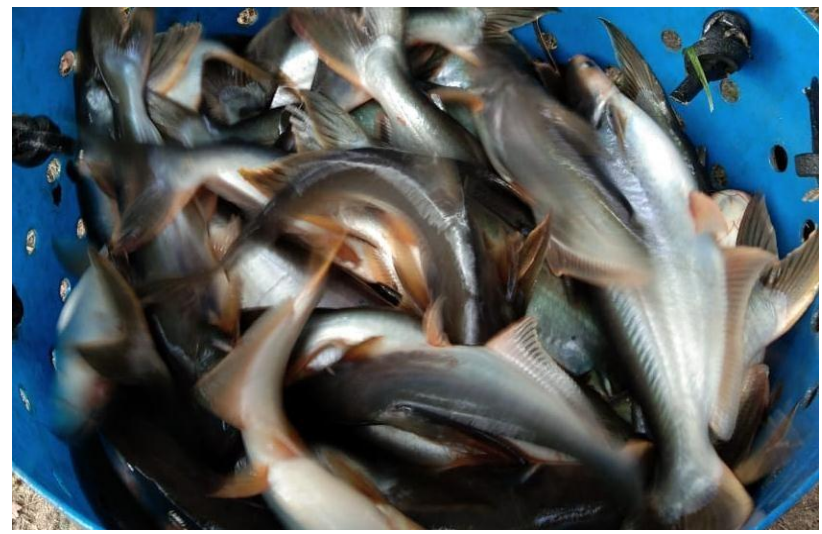

Gambar 1. Ikan Patin

Kelompok Budidaya Ikan (Pokdakan) Mina Usaha merupakan salah satu Pokdakan yang terdapat di Kelurahan Rumbai Bukit Kecamatan Rumbai Kota Pekanbaru yang telah berdiri sejak tahun 1997 dengan luas $7.710 \mathrm{~km} 2$ dan terdapat 14 kolam dengan ukuran $20 \times 25 \mathrm{~m} 2$ dan $30 \times 25 \mathrm{~m} 2$ (Gambar 2). Pokdakan ini diketuai oleh Bapak Zabur. Ikan patin merupakan spesies ikan yang dibudidayakan, dengan jumlah produksi 3-6 ton setiap panen. Untuk mengantisipasi kelimpahan produksi ikan patin, dan memperpanjang masa simpannya maka dilakukan pengolahan ikan patin dalam bentuk diversifikasi produk berupa snack ikan aneka flavour. Mengingat selama ini masyarakat hanya mengetahui pemanfaatan ikan patin hanya dalam bentuk segar yakni dimasak berupa asam pedas, gulai dan digoreng.

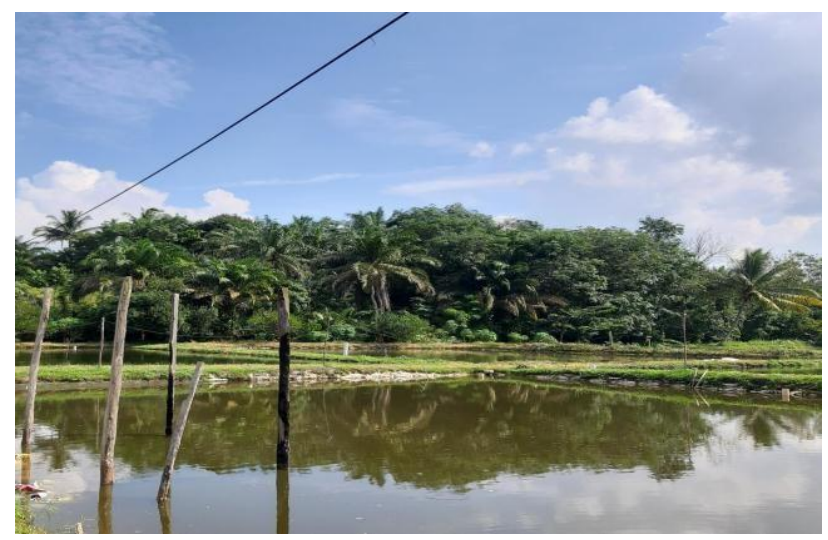

Gambar 2. Kolam Budidaya Ikan Patin Pokdakan Mina Usaha

Snack ikan patin merupakan salah satu alternatif makanan sehat yang kaya akan protein dan zat gizi lainnya yang diperlukan tubuh, yang tidak hanya untuk pertumbuhan tetapi juga untuk kecerdasan otak. Snack ikan merupakan cemilan sehat yang rapuh dan renyah sehingga dapat dimakan kapan saja, dan siapapun bisa memakannya tidak hanya orang tua tapi juga anak-anak. Seiring dengan perkembangan teknologi pangan, teknologi pengolahan snack ikan juga berkembang, baik dalam segi bentuk, variasi flavour, dimana 
pengolahan snack ikan yang dilakukan di Kelurahan Rumbai Bukit tediri dari 3 flavour yaitu keju, barbeque, dan balado.

Melalui kegiatan pengabdian kepada masyarakat ini diharapkan masyarakat petani ikan, khususnya isteri kelompok Tani Mina Usaha Kelurahan Rumbai Bukit Kecamatan Rumbai Pekanbaru, dapat melakukan kegiatan produktif yang dapat menunjang kesejahteraan mereka. Disamping itu, apabila teknik pengolahan snack ikan ini diterima dan dikembangkan oleh masyarakat Kelurahan Rumbai Bukit, bahkan dapat diperluaskan diwilayah seluruh Kota Pekanbaru, maka diharapkan produk snack ikan dapat menjadi salah satu produk unggulan berbasis ikan.

\section{Masalah}

Adapun masalah yang dihadapi oleh masyarakat petani ikan, di Kelurahan Rumbai Bukit adalah:

1. Terbatasnya pengetahuan dan keterampilan kelompok petani ikan Kelurahan Rumbai Bukit Kecamatan Rumbai tentang teknik pengolahan ikan dan diversifikasi hasil perikanan

2. Anggota kelompok petani ikan memiliki banyak waktu luang, tetapi kurang produktif

3. Kurangnya pemahaman tentang manajemen dan pengendalian mutu hasil perikanan

\section{Tujuan kegiatan pengabdian}

Memberikan kemampuan dan keterampilan praktis kepada masyarakat kelurahan Rumbai Bukit Pekanbaru dalam pembuatan snack ikan patin aneka flavour yang bernilai gizi tinggi sehingga dapat meningkatkan konsumsi protein ikan bagi anggota keluarga dan diharapkan dapat mengembangkannya dalam bentuk industri skala rumah tangga atau kelompok industri kecil di daerah ini sehingga dapat membantu perekonomian keluarga.

\section{METODE PENERAPAN}

Adapun metode yang digunakan dalam kegiatan pengabdian kepada masyarakat ini adalah

1. Metode survey, wawancara dan observasi

Metode survey dilakukan untuk mengetahui lokasi Pokdakan dan tempat kegiatan pengabdian kepada masyarakat dilakukan. Wawancara dilakukan pada Bapak Lurah, ketua Pokdakan, dan masyarakat Kelurahan Rumbai Bukit mengenai peserta yang terlibat dalam kegiatan dan informasi terkait pelaksanaan kegiatan ini. Metode observasi dilakukan terhadap kegiatan pengolahan yang dilakukan, yang dimulai dari proses pembersihan ikan patin, pemfilletan hingga pembuatan snack ikan patin aneka flavour.

2. Metode Ceramah dan Diskusi

Sebelum kegiatan pelatihan pengolahan snack ikan patin dilakukan, terlebih dahulu dilakukan kegiatan penyuluhan berupa materi tentang: 1) metode penanganan produk perikanan (ikan) yang benar; 2) cara memfillet ikan, 3) teknik pengolahan snack ikan aneka flavour 4) metode packaging (pengemasan) dan labelling (pembuatan label); 5) penyimpanan dan pemasaran snack ikan; dan 6) manajemen pengendalian mutu untuk menjamin keamanan produk. Setelah pemberian materi dilakukan oleh tim pengabdian kepada masyarakat secara bergantian, dilanjutkan dengan sesi diskusi/tanya jawab.

3. Metode Pelatihan

Metode pelatihan terdiri dari tahap persiapan dan pelaksanaan.

a. Tahap Persiapan

Persiapan yang dilakukan antara lain, penyediaan alat masak berupa pisau, baskom, penggiling daging, sendok dan talenan, kuali, timbangan, alat pencetak snack ikan, kompor, penyediaan bumbu-bumbu dan bahan-bahan masak berupa minyak goreng, garam, tepung kanji, tepung ketan, keju, telur, dan air es. Selain itu juga dipersiapkan sejumlah alat peraga dan makalah kit tentang materi penyuluhan dan penyediaan contoh snack ikan yang sudah jadi. Selain itu juga dipersiapkan sejumlah alat peraga dan makalah kit tentang materi penyuluhan dan penyediaan contoh snack ikan yang sudah jadi.

b. Tahap Pelaksanaan

Pelaksanaan kegiatan dimulai dengan kata pembukaan dan sambutan oleh Lurah Rumbai Bukit Kecamatan Rumbai Pekanbaru (Bapak Nanda Eddyan Harsono, S.STP), dan dilanjutkan kata sambutan dari mitra kegiatan/Ketua Pokdakan Mina Usaha (Bapak Zabur), kemudian dilanjutkan oleh tim pengabdian kepada masyarakat dihadapan 20 orang peserta kegiatan pengabdian kepada masyarakat dan 10 orang Mahasiswa Kuliah kerja nyata (Kukerta) Universitas Riau terintegrasi pengabdian kepada masyarakat. 
Setelah kata pembukaan dan sambutan, maka acara intipun dilaksanakan yaitu tentang pengolahan snack ikan aneka flavour yang dipandu langsung oleh ketua pelaksana, anggota tim pengabdian lainnya, dan Mahasiswa Kukerta.

\section{Teknik pengumpulan data}

Data yang dikumpulkan berupa data primer dan data sekunder. Data primer diperoleh dari wawancara langsung dari sumber yang terkait yakni Lurah, Ketua Pokdakan dan masyarakat yang merupakan peserta kegiatan pengabdian ini. Data sekunder merupakan data penunjang yang diperoleh dari sumber bacaan yang bersifat tidak langsung yang terkait dengan pengolahan snack ikan.

\section{Teknik analisis data}

Data yang didapat dianalisis secara deskriptif dan digambarkan secara sistematis mengenai kegiatan pengabdian kepada masyarakat ini.

\section{Lokasi}

Kelurahan Rumbai Bukit Kecamatan Rumbai Kota Pekanbaru merupakan lokasi kegiatan pengabdian kepada masyarakat yang berjarak $\pm 21,9$ km dari kampus Universitas Riau Panam Pekanbaru.

\section{Waktu, dan durasi kegiatan}

Kegiatan pengabdian kepada masyarakat ini dilaksanakan selama 3 bulan, yaitu dari bulan Mei, Juni dan Juli 2019, dengan beberapa tahap yaitu tahap persiapan (penetapan daerah dan penseleksian calon peserta) dan tahap pembelajaran (pelatihan).

\section{PEMBAHASAN}

Pelaksanaan kegiatan pengabdian kepada masyarakat mengenai pelatihan pembuatan snack ikan patin aneka flavour diawali dengan pengambilan daging ikan patin. Mengingat ikan patin merupakan salah satu jenis ikan yang sedang dibudidayakan didaerah ini. Adapun luaran dari kegiatan ini terciptanya snack ikan aneka flavour yang bernilai gizi tinggi, dan siap dikonsumsi oleh seluruh lapisan masyarakat, serta melatih masyarakat di Kelurahan Rumbai Bukit dalam pembuatan snack ikan sehingga dapat meningkatkan skill mereka. Beberapa tahapan dalam pembuatan snack ikan dari awal proses sampai akhir dapat diuraikan sebagai berikut.

\section{Pengambilan Daging Ikan Patin}

Adapun langkah-langkah dalam pengambilan daging ikan patin sebagai berikut:

1. Ikan patin yang masih segar dibersihkan dengan cara dicuci

2. Daging ikan patin difillet dan dibuang kulitnya

3. Lalu dihaluskan dan siap untuk diolah menjadi snack ikan aneka flavour

\section{Pengolahan Snack Ikan Patin}

Komposisi bahan-bahan yang digunakan untuk pembuatan 1000 gr daging ikan patin dapat dilihat pada tabel 1.

Tabel 1. Komposisi bahan-bahan snack ikan patin

\begin{tabular}{lc}
\hline \multicolumn{1}{c}{ Bahan-bahan } & Jumlah (gr) \\
\hline Daging ikan patin & 1000 \\
Tepung kanji & 4000 \\
Tepung ketan & 1000 \\
Keju & 440 \\
Telur & 40 butir \\
MSG & Secukupnya \\
Flavour keju, barbeque dan balado & Secukupnya \\
Minyak goreng & Secukupnya \\
\hline
\end{tabular}


Adapun pengolahan fish snack ikan patin menurut (BPPMHP, 2005):

1. Ikan disiangi dan difillet, dicuci sampai bersih dan terakhir dicuci dengan air es

2. Daging digiling dengan blender sampai halus

3. Daging ikan, tepung, dan bumbu dimasukkan ke dalam wadah kemudian aduk hingga kalis (diaduk hingga rata)

4. Adonan dicetak dengan alat pencetak snack ikan

5. Snack yang telah dicetak digoreng dengan minyak yang telah dipanaskan dengan suhu 180 0C selama 5 menit

6. Snack ikan patin telah jadi, siap dimakan langsung dengan rasa original atau ditambahkan flavour barbeque dan balado.

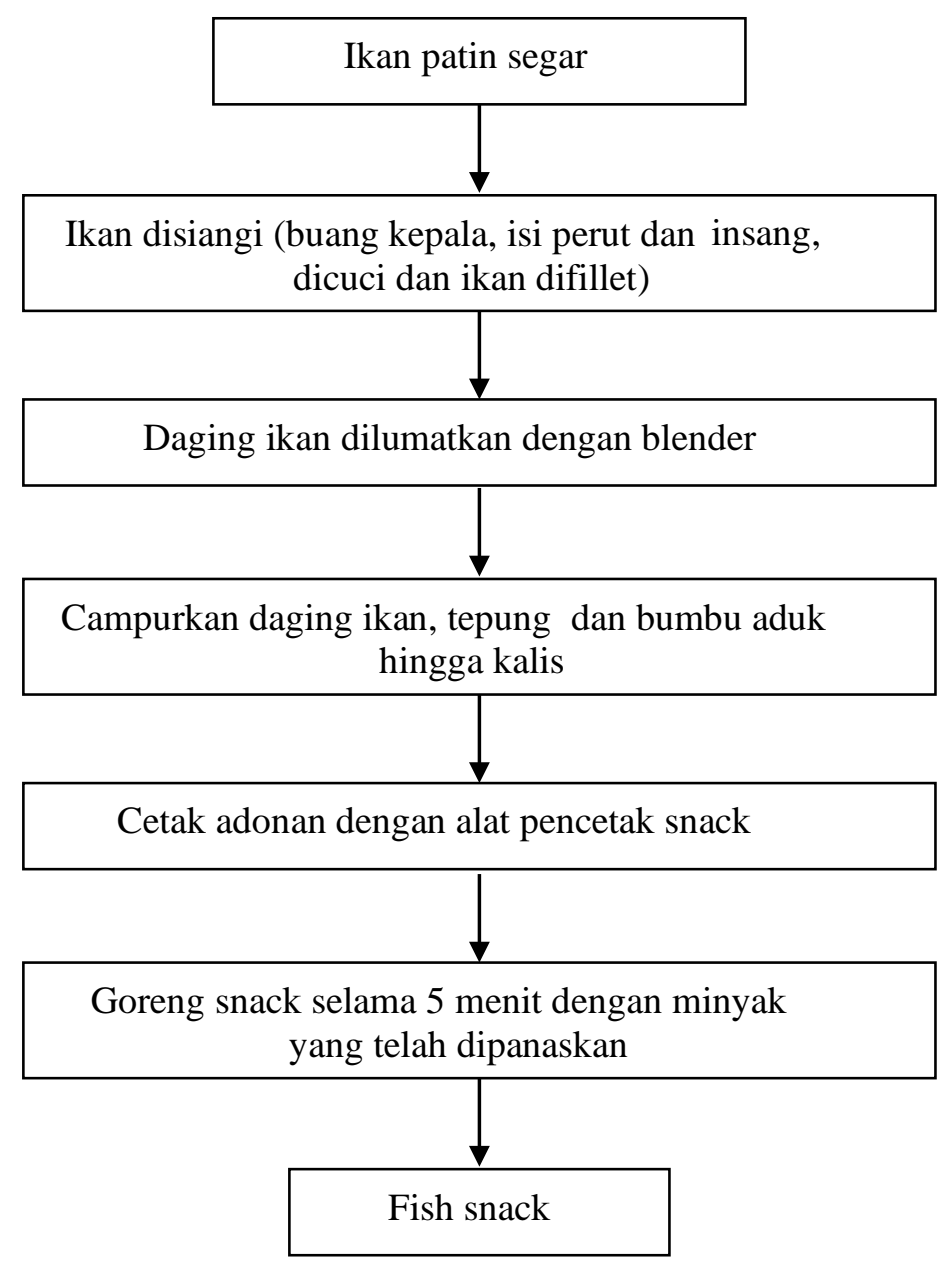

Gambar 3. Skema Pembuatan Snack Ikan Patin

\section{Packaging (pengemasan) dan labelling (pembuatan label)}

Produk olahan snack ikan patin aneka flavour yang telah jadi, dimasukkan kedalam plastik Zipper standing pouch PP yang berukuran $14 \times 22 \times 0,1 \mathrm{~cm}$ yang sudah dilabel berdasarkan flavournya, lalu ditutup. Informasi yang ditulis dilabel berupa "komposisi bahan bahan pembuatan snack ikan patin, flavour, dan diproduksi oleh". Setelah itu, snack ikan patin aneka flavour yang telah dikemas siap disimpan dan dipromosikan, baik disekitaran Kelurahan Rumbai Bukit Kecamatan Rumbai, maupun seluruh area Kota Pekanbaru.

\section{Penyajian snack ikan patin}

Penyajian snack ikan patin dapat dilakukan dengan cara langsung dimakan, kapanpun dan dimanapun, atau dapat juga disajikan pada saat hari raya sebagai cemilan yang sehat dan bergizi. 


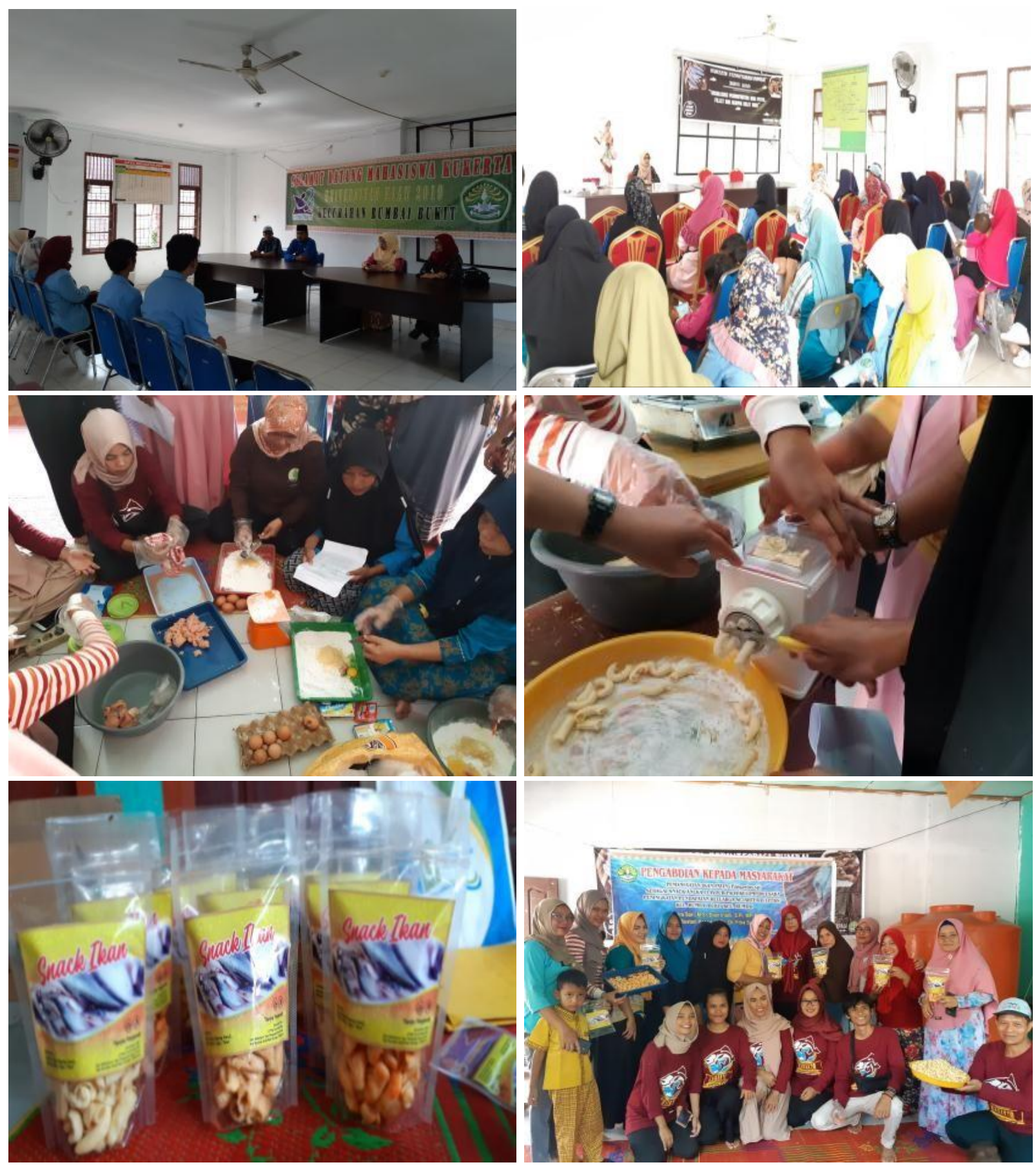

Gambar 4. Dokumentasi kegiatan pengabdian kepada masyarakat di Kelurahan Rumbai Bukit Kecamatan Rumbai, Pekanbaru

Luasnya kolam ikan dan tersedianya bahan baku berupa ikan patin di Pokdakan Mina Usaha milik warga di Kelurahan Rumbai Bukit merupakan salah satu keunggulan dalam pembuatan snack ikan patin. Karena masyarakat tidak perlu bersusah payah lagi mencari ikan yang merupakan bahan utama dalam memproduksi snack ini. Adapun kelemahan dari kegiatan ini, belum tersedianya ruangan khusus untuk proses pengolahan snack ikan.

Pada pembuatan snack ikan patin ini, memerlukan alat pencetak snack agar snack yang dihasilkan seragam dan memiliki bentuk khas seperti makaroni. Untuk itu demi kelancaran proses produksi , tim pengabdian memberikan bantuan alat berupa alat pencetak snack. Melalui alat pencetak ini dapat mendorong masyarakat untuk dapat memproduksi snack ikan. Hal ini disebabkan karena produk makanan ini memiliki peluang yang sangat besar untuk dikembangkan, baik dilingkungan sekolah, pasar, maupun swalayan. Ditambah lagi snack ikan ini merupakan produk makanan kaya gizi dan dapat dikonsumsi oleh segala usia. 


\section{KESIMPULAN}

Antusias peserta kegiatan pengabdian yang sangat tinggi dan semangat yang diberikan oleh Bapak Lurah Kelurahan Rumbai Bukit Kecamatan Rumbai, Pekanbaru membuat acara pelatihan pengolahan snack ikan patin ini berjalan dengan lancar dan sukses. Berdasarkan post test yang diberikan, menunjukkan bahwa 95\% peserta telah mengetahui tentang diversifikasi produk olahan hasil perikanan, enterpreneurship, serta teknik pengemasan dan pelabelan produk. Selain itu, peserta dapat membuat produk snack ikan ini baik secara perorangan maupun kelompok. Dengan demikian, para peserta telah dapat menciptakan pangan bergizi bagi keluarga maupun masyarakat. Untuk kegiatan pengabdian kedepannya, adanya diversifikasi produk olahan ikan patin lainnya dan upaya pemasaran produk yang dihasilkan sehingga dapat meningkatkan pendapatan peserta pengabdian.

\section{UCAPAN TERIMAKASIH}

Terimakasih kepada lppm universitas riau yang telah memberi bantuan dana kegiatan pengabdian kepada masyarakat ini melalui dana dipa universitas riau tahun 2019 dengan nomor kontrak 455/un.19.5.1.3/pt.01.03/2019.e

\section{DAFTAR PUSTAKA}

Balai Pengembangan dan Pengujian Mutu Hasil Perikanan (BPPMHP). 2005. Laporan Tahunan Perekayasaan Teknologi Fish Jelly Product. BPPMHP Jakarta.

Domiszewski, Z., G. Bienkiewicz, \& D. Plust. 2011. Effects of Different Heat Treatments on Lipid Quality of Striped Catfish (Pangasius hypophthalmus). Acta Scientiarum Polonorum, Technol. Aliment, 10(3), 359-373.

Oyewole, O. E., \& Amosu, A. M. 2012. Nutritional considerations and benefits associated with consumption of catfish in South- West Nigeria. Scholars Research Library. Annals of Biological Research, 3(8), 4094-4098.

Viji, P., Tanuja, S, Ninan, G, Lalitha, K. V, Zynudheen, A. A, Binsi, P.K, \& Srinivasagopal, T. K. 2014. Biochemical, textural, microbiological and sensory attributes of gutted and ungutted sutchi catfish (Pangasianodon hypophthalmus) stored in ice. Journal of Food Science and Technology, 52(6), 3312-3321. http://doi.org/10.1007/s13197-014-1358-y 